\title{
ЗАХИСТ ПРАВ МАЛОЛІТНІХ І НЕПОВНОЛІТНІХ ОСІБ У ЦИВІЛЬНОМУ СУДОЧИНСТВІ ЯК НАУКОВА ПРОБЛЕМА
}

\author{
ПІЛЯК Назар Іванович - аспірант кафедри цивільного права і процесу, \\ Національна академія внутрішніх справ, Україна, м. Київ \\ ORCID ID: 0000-0001-6859-2434 \\ УДК 347.641 \\ DOI 10.32782/NP.2020.4.20
}

В статье анализируется состояние научной проблемъ относительно защить прав малолетних и несовершеннолетних лии при рассмотрении гражданских дел судами. При использовании методов научного познания объясняется необходимость постоянного поиска законодательнъх путей к усовершенствованию процедур защить указаннъих субъектов. Вместе с тем, описвивается на теоретическом уровне содержание гражданской процессуальной правосуббектности таких лич с обоснованием ее специфичности и уникальности в гражданском прочессуальном праве. Упоминание ряда нормативно-правовых актов, предметом которьх является материально- $и$ процессуально-правовое регулирование соответствующих правоотношений, свидетельствует о значимости тематики исследования при соблюдении Украиной принятъих для исполнения международно-правовъгх обязательств. Указъвается на постоянное усовершенствование законодательно-предусмотренных процедур и оснований защить прав детей, в том числе в связи с противодействием домашнему насильству, привлечением в качестве свидетелей, признания Факта их рождения на временно-оккупированной территории.

Ключевъе слова: защита прав в гражданском судопроизводстве; малолетние и несовершеннолетние лища; гражданская процессуальная правосубъектность; рассмотрение дел судами; правоспособность; дееспособность; противодействие домашнему насильству.
Постановка проблеми в загальному вигляді та їі зв'язок із важливими науковими та практичними завданнями полягає у постійному вдосконаленні правового статусу тих чи інших суб'єктів цивільних процесуальних правовідносин. Не є винятком і намагання законодавця вдосконалити захист прав малолітніх та неповнолітніх осіб при розгляді цивільних справ. Враховуючи правовий статус дитини як особи до досягнення нею повноліття (ч.1 ст.6 СК України), увага до ії прав, свобод та інтересів зосереджується не лише в нормах національного права, а й у міжнародно-правових актах. Зокрема, за даними Міністерства Юстиції України, мова іде про Конвенцію ООН про права дитини. Цей нормативний акт $є$ основним документом, що визначає правові стандарти у сфері захисту прав дитини. Конвенція ратифікована Україною 27 лютого 1991 р. і набула чинності 27 вересня $1991 \mathrm{p}$.

Важливе значення має також ратифікація низки міжнародних договорів у сфері сімейного права, які розроблені в рамках Ради Європи та Гаазької конференції $з$ міжнародного приватного права. Ці документи дозволяють вирішувати практичні питання, котрі стосуються здійснення прав дітей, а також регулюють відносини батьків і дітей як матеріальні, так і особисті. Деякі 3 таких договорів були підписані Україною ще у 2002 - 2003 роках.

Поряд із вказаним, у 2006 році було ратифіковано: Конвенцію про цивільно- 
правові аспекти міжнародного викрадення дітей 1980 р.; Європейську конвенцію про здійснення прав дітей 1996 р.; Конвенцію про юрисдикцію, право, що застосовується, визнання, виконання та співробітництво щодо батьківської відповідальності та заходів захисту дітей 1996 р.; Конвенцію про контакт 3 дітьми 2003 р.; Конвенцію про стягнення аліментів за кордоном 1956 р. та Конвенцію про визнання і виконання рішень стосовно зобов'язань про утримання 1973 р. У 2008 році ратифіковано Европейську конвенцію про визнання та виконання рішень стосовно опіки над дітьми та про поновлення опіки над дітьми 1980 р. У січні 2009 року Верховна Рада України ратифікувала Европейську конвенцію про правовий статус дітей, народжених поза шлюбом 1975 р. [1].

Аналіз останніх досліджень та публікацій, що започаткували вирішення цієї проблеми, на які спирається автор, дозволяє приділити увагу специфіці захисту прав, свобод та інтересів дітей в порядку цивільного судочинства з огляду на обсяг їх цивільної процесуальної правосуб'єктності. Ці питання стали предметом наукових досліджень С.С. Бичкової, К.В. Гусарова,В.В. Комарова, Г.В. Чурпіти [2-5] та інших дослідників. У закордонній правничій літературі, поряд 3 цим, обговорюються не менш важливі питання, пов'язані із судовим захистом прав неповнолітніх, що стали жертвами торгівлі людьми [6], із особливостями реалізації неповнолітніми прав на азартні ігри [7], та інші проблеми реалізації їх правосуб’єктності.

Не вирішені частини загахьної проблеми, яким присвячується стаття, полягають у необхідності дослідження змісту та порядку реалізації цивільної процесуальної правосуб'єктності малолітніх та неповнолітніх осіб.

Постановкою завдання цієї наукової роботи є викладення наукової проблеми захисту прав малолітніх і неповнолітніх осіб при розгляду цивільних справ судами.
Викладення основного матеріалу 3 обгрунтуванням отриманих результатів грунтується на використанні при провадженні дослідження методів наукового пізнання. Відносно дослідження предмету роботи важливим є і те, що ст. 51 Конституції України передбачає обов'язок батьків утримувати дітей до їх повноліття. Сім'я, дитинство, материнство і батьківство охороняються державою. Також на державу покладається утримання і виховання дітейсиріт і дітей, позбавлених батьківського піклування. 3 боку держави гарантується заохочення і підтримання благодійницької діяльності щодо дітей (ч.3 ст.52 Конституції України). При порушенні вказаних гарантій їх захист забезпечується застосуванням багатьох механізмів. У їх межах мова іде, зокрема, і про можливість участі дітей (малолітніх і неповнолітніх осіб) при розгляді справ, передусім, судами цивільної юрисдикції, відносно захисту їх цивільних (у широкому розумінні) прав, свобод та охоронюваних законом інтересів.

«Поділ» дітей як суб'єктів цивільних та цивільних процесуальних правовідносин на малолітніх та неповнолітніх пояснюється змістом їх правосуб'єктності, визначеним ст. ст. 31 та 32 ЦК України. Перша із вказаних норм до малолітньої особи відносить фізичних осіб, які не досягли чотирнадцяти років. Законодавець надав їм обсяг дієздатності, що називається частковою. Її зміст зводиться до можливості малолітніх осіб: 1) самостійно вчинювати дрібні побутові правочини, та 2) здійснювати особисті немайнові права на результати їх інтелектуальної і творчої діяльності, що охороняються законом. До особливостей цивільної дієздатності вказаних осіб слід віднести і ту обставину, що малолітня особа не несе відповідальність за шкоду, завдану нею.

Фізичні особи у віці від чотирнадцяти до вісімнадцяти років мають, згідно із ст. 32 ЦК України, неповну цивільну дієздатність. Остання включає в себе, крім часткової дієздатності, також права щодо: 1) самостійного розпорядження своїм заробітком, стипендією або іншими доходами; 2) самостійного здійснення права на результати творчої, інтелектуальної діяльнос- 
ті, що охороняються законом; 3) набуття статусу учасника (засновника) юридичних осіб у випадках, якщо це не заборонено ані законом, ані установчими документами юридичної особи; 4) самостійного укладання договору банківського вкладу (рахунку) та розпорядження ним за умови внесення цією особою на своє ім'я (грошових коштів на рахунку). До особливості цивільної дієздатності відноситься і та обставина, що неповнолітня особа вправі вчиняти інші правочини за наявності згоди батьків (усиновлювачів) або піклувальників. На вчинення неповнолітньою особою правочину відносно транспортних засобів чи нерухомого майна має бути письмова згода батьків (усиновлювачів) або піклувальників, посвідченій у нотаріальній формі, поряд із дозволом органу опіки та піклування. Така письмова нотаріально-посвідчена згода батьків (усиновлювачів) або піклувальників, разом із дозволом органу опіки та піклування, обов'язкова і при розпорядженні неповнолітньою особою грошовими коштами, що внесені повністю або частково іншими особами до фінансової установи на ім'я неповнолітнього. У той же час, за заявою батьків (усиновлювачів) цієї особи, їі піклувальника, органу опіки та піклування суд, за наявності достатніх підстав, може обмежити надання неповнолітній особі право самостійного розпорядження власним заробітком, стипендією чи іншими доходами, або позбавити іiі такого права. У разі відсутності обставин, що були підставою для ухвалення рішення про обмеження (позбавлення) зазначеного права, суд скасовує власне рішення. Разом з визначеним, ст. 33 ЦК України визначає особливості цивільної відповідальності неповнолітньої особи, а ст. 35 вказаного Кодексу - випадки надання повної цивільної дієздатності неповнолітній фізичній особі.

На відміну від такої регламентації структури дієздатності у цивільному матеріальному праві малолітніх та неповнолітніх осіб, сутність цивільної правоздатності має більш просту побудову. Частина 1 ст. 25 ЦК України визначає цивільну правоздатність як здатність усіх фізичних осіб мати цивільні права та обов'язки. Вона виникає у момент народження дитини та припиняється в момент їі смерті. Усіх фізичних осіб об'єднує рівність у здатності мати цивільні права та обов'язки.

Суттєву відмінність має правове регулювання цивільної процесуальної правоздатності. На відміну від правоздатності у цивільному матеріальному праві, здатність мати цивільні процесуальні права та обов’язки мають фізичні і юридичні особи, проте не всі суб'єкти цивільних процесуальних правовідносин. Стаття 46 ЦПК України закріплює таку властивість для сторін, третіх осіб, заявників та заінтересованих осіб. На відміну від цього, цивільна процесуальна дієздатність розуміється як здатність юридичних та повнолітніх фізичних осіб особисто здійснювати цивільні процесуальні права та виконувати свої обов'язки в суді (ст. 47 ЦПК України). Цей нормативний акт не передбачає розгалужені (на відміну від ЦК України) різновиди дієздатності малолітніх та неповнолітніх осіб. Частини 2 та 3 вказаної норми не передбачають особливості змісту цивільної процесуальної дієздатності малолітніх осіб. Проте ч.1 ст. 59 ЦПК України передбачає захист прав, свобод та інтересів малолітніх осіб віком до чотирнадцяти років їхніми батьками, усиновлювачами, опікунами чи іншими особами, визначеними законом.

Неповнолітні ж особи віком від чотирнадцяти до вісімнадцяти років можуть особисто реалізовувати цивільні процесуальні права та здійснювати свої обов'язки в суді по справах, які виникають 3 відносин, у яких вони особисто брали участь. Суд може залучити до участі у такій справі законного представника неповнолітньої особи. В іншому випадку (ч.3 ст.47 ЦПК України) фізична особа, яка не досягла повноліття, набуває цивільної процесуальної правоздатності з моменту реєстрації шлюбу. Повна цивільна процесуальна дієздатність може надаватись неповнолітній особі в судовому порядку за правилами, встановленими ЦПК України.

Таке ретельне описування структури дитячої право- та дієздатності пояснюється необхідністю висвітлення наукового інтересу до дослідження особливостей захис- 
ту прав малолітніх та неповнолітніх осіб у порядку цивільного судочинства. 3 практичної точки зору інтерес до висвітлення вказаних питань можна пояснити даними судової статистики. За спостереженнями автора, оприлюдненими ним в одній 3 наукових публікацій, кількість рішень судів цивільної юрисдикції щодо захисту прав малолітніх та неповнолітніх осіб становить декілька десятків тисяч у період з 2017 по грудень 2020 років [8]. У зв'язку з цим практичний сенс має з'ясування доцільності запровадження спеціалізації суддів щодо захисту в порядку цивільного судочинства прав, свобод та інтересів вказаних вище осіб. Не претендуючи на остаточність вирішення цього питання уявляється, в якості одного з аргументів на користь даної позиції можна навести запровадження на нормативному Міжвідомчої координаційної ради з питань правосуддя щодо неповнолітніх. Проте у п.3 Положення про вказану раду мова іде про забезпечення інтересів неповнолітніх, які вчинили кримінальні правопорушення, стали жертвами або свідками злочинів, а також про підготовку пропозицій щодо запровадження ефективного правосуддя стосовно неповнолітніх, котрі вчинили правопорушення, з урахуванням їх вікових, соціально-психологічних, психофізичних й інших особливостей [9]. Вважаю, що з урахуванням вказаних вище особливостей неповнолітніх доцільно розширити підготовку нормативних актів і щодо правового закріплення особливостей розгляду судами цивільної юрисдикції справ, у яких зазначені особи набули процесуальноправового статусу суб'єктів цивільних процесуальних правовідносин 3 урахуванням правосуб'єктності сторони, заявника, третьої особи тощо.

Актуальність цих питань потребує більш ретельної уваги і у зв’язку із правовими наслідками збройної агресії Російської Федерації проти України, оскільки факт народження малолітньої дитини на тимчасово окупованій території нашої держави підлягає встановленню із дотриманням спеціальної процедури, передбаченій ст. 317 ЦПК України. Разом 3 тим, не можна не відмітити інтерес законодавця та його на- магання до вдосконалення запобігання домашньому насильству. Вітчизняний ЦПК України при його рекодифікації у 2017 р. був доповнений і відповідною главою окремого провадження, яка регламентує процедуру розгляду судом справ про видачу i продовження обмежувального припису, яка нерідко стосується прав, свобод та інтересів дітей. У процесуальній літературі відмічаються наступні особливості розгляду таких справ. Передусім це суттєво звужені строки їх розгляду. Відповідно до ч.2 ст. 350-5 ЦПК України, справа про видачу обмежувального припису повинна розглядатись судом не пізніше 72 годин від надходження заяви про видачу обмежувального припису до суду. Наступна особливість полягає в тому, що процесуальна форма розгляду цих цивільних справ закріплена не лише у нормах ЦПК України, а і Закону України «Про запобігання та протидію домашньому насильству». Звертає на себе увагу і введення до суб'єктного кола цивільних процесуальних правовідносин такої особи, як кривдник, а також відсутність обов'язку додавання до заяви про видачу обмежувального припису доказів вчинення домашнього насильства. Пункт 3 ч. 350-4 ЦПК України дозволяє вказувати у заяві обставини, які свідчать про необхідність видачі обмежувального припису судом та докази, котрі їх підтверджують (за наявності). Потребують уваги і інші особливості цих справ окремого провадження, що викладені у роботі, яка цитується [10].

Редакція оновленого ЦПК України передбачає, крім зазначеного, можливе врегулювання судом правовідносин, пов'язаних iз виконанням правоздатною особою функцій законного представника малолітніх та неповнолітніх фізичних осіб (ст. 63 ЦПК України).

Разом $з$ цим, захист цивільних прав та інтересів дітей під час розгляду справ судами не обмежується лише вищезазначеними питаннями. Малолітні та неповнолітні особи набувають цивільну процесуальну правосуб'єктність не лише як учасники справи (за виключенням малолітніх), a i як, наприклад, свідки. Зміст ст. 232 ЦПК України дозволяе виокремити наступні 
особливості порядку допиту в суді малолітніх і неповнолітніх свідків: 1) допит малолітніх (за розсудом суду і неповнолітніх) свідків відбувається в присутності батьків або інших законних представників за умови, якщо вони не заінтересовані у справі; 2) свідок, який не досяг шістнадцятирічного віку, не попереджається судом про юридичну відповідальність за відмову від давання показань і за давання завідомо неправдивих показань, та не приводиться до присяги; 3) при необхідності, на час допиту неповнолітніх свідків, із зали судового засідання за ухвалою суду може бути видалений учасник справи із наступним повідомленням йому про показання і з наданням можливості ставити свідкові питання; 4) видалення свідка, який не досяг шістнадцятирічного віку, із зали судового засідання після закінчення його допиту, за винятком визнання судом необхідності його присутності в залі судового засідання.

Висновок із зазначеного полягає в тому, що викладення вищенаведеного матеріалу зумовлює необхідність дослідження реалізації цивільної процесуальної правосуб'єктності малолітніх і неповнолітніх осіб під час розгляду цивільної справи судом. Не претендуючи на остаточність власних міркувань, автор вважає за доцільне запровадження подальших наукових дискусій щодо проблематики захисту прав малолітніх та неповнолітніх осіб у цивільному судочинстві.

\section{\ітература}

1. Захист прав дітей в Україні з урахуванням міжнародних договорів з питань сімейного права //Eл. pecypc: https://minjust. gov.ua/m/str_19188

2. Бичкова, С.С. Правове регулювання патронату над дітьми в Україні: прогалини та колізії //Вісник Національної академії правових наук України. - 2020. - №1, T.2. - C.131-146.

3. Гусаров, К. В. Проблеми цивільної процесуальної правосуб'єктності: автореф. дисс. ... канд. юрид. наук: 12.00.03 / К. В. Гусаров; Національна юридична академія України імені Ярослава Мудрого. - Х., 2000. - 19 с.

4. Цивільне судочинство України: основні засади та інститути: монографія /-В. В. Комаров, К. В. Гусаров, Н. Ю. Сакара та ін.: Х.: Право, 2016, 848 с.

5. Чурпіта, Г.В. Деякі аспекти судового захисту сімейних прав та інтересів //Вісник Національної академії правових наук України. - 2020. - №1, T.2. - С. 71-83.

6. Jardí, M.S. The protection of the family life of displaced persons, asylum applicants, refugees, and stateless persons in European law [La protección de la vida familiar de las personas desplazadas, de las demandantes de asilo, de las refugiadas y de las apátridas en el derecho europeo] (2016) Revista de Derecho Politico, (95), pp. 190-227.

7. Nelson Rose, I. Underage gambling and the law ${ }^{\circledR}$ (2003) Futures at Stake: Youth, Gambling, and Society, pp. 126-189.

8. Піляк, Н.I. Цивільна процесуальна правосуб'єктність малолітніх і неповнолітніх осіб як учасників цивільної справи. Теорія і практика правознавства, [S.I.], v. 2, n. 18, p. 7, Dec. 2020. ISSN 2225-6555. Доступно за адресою: < http://tlaw.nlu.edu.ua/ article/view/218964 $>$. Дата доступу: 24 Dec. 2020 doi:http://dx.doi.org/10.21564/22256555.2020.18.218964.

9. Постанова Кабінету Міністрів України від 24.05.2017 р. № 357 «Про утворення Міжвідомчої координаційної ради 3 питань правосуддя щодо неповнолітніх» // Eл. pecypc: https://zakon.rada.gov.ua/laws/ show/357-2017-\%D0\%BF\#n9

10. Гусаров, К.В. Особливості розгляду судами справ про видачу обмежувального припису //Юридична Україна, 2020. - №1, C. 65-67.

\section{Piliak Nazar \\ THE PROTECTION OF THE RIGHTS OF MINORS AND JUVENILES IN GIVIL PROGEEDINGS AS A SCIENTIFIC PROBLEM}

In the article it is being analyzed the state of the scientific problem regarding the protection of the minors' rights in civil cases by courts. Using the methods of scientific knowl- 
Піляк Н.І. - Захист прав малолітніх і неповнолітніх осіб у цивільному судочинстві...

\section{АНОТАЦІЯ}

у статті аналізується стан наукової проблеми відносно захисту прав малолітніх i неповнолітніх осіб при розгляді изивільних справ судами. При використанні методів наукового пізнання пояснюеться необхідність постійного пошуку законодавчих шляхів до вдосконалення процедур захисту вказаних суб’єктів. Поряд з иим, описується на теоретичному рівні зміст ицвільної процесуальної правосуб'єктності вищевказаних осіб iз обгрунтуванням ї специфбінності та унікальності у изивільному процесуальному праві. Зазначення низки міжнародно-правових актів, предметом яких є матеріально- та процесуально-правове регулювання вказаних правовідносин, свідчить про значущість тематики дослідження при дотриманні Україною прийнятих на себе міжнародно-правових зобов'язань. Вказується про постійне вдосконалення на законодавчому рівні процедур та підстав захисту прав дітей, зокрема у зв'язку із протидією домашньому насильству, залучення в якості свідків, визнання фбакту їх народження на тимчасово-окупованій теpumopii.

Ключові слова: захист прав у ицвільному судочинстві; малолітні і неповнолітні особи; ицвільна процесуальна правосуб'єктність; розгляд справ судами; правоздатність; дієздатність; протидія домашньому насильству. edge is explained as the necessity for constant search for legislative ways to improve the procedures for the protection of these entities. The content of the civil procedural legal personality of the above-mentioned persons is described on a theoretical level with the substantiation of its specificity and uniqueness in civil procedural law. The indication of a number of international legal acts, the subject of which is the substantive and procedural legal regulation of these legal relations, testifies to the importance of the research topic in compliance with Ukraine's international legal obligations. It indicates the constant improvement at the legislative level of procedures and basis for the protection of children's rights, in particular in connection with the fight against domestic violence, the involvement as witnesses, recognition of the fact of their birth in the temporarily occupied territory.

Key words: protection of rights in civil proceedings; minors and juveniles; civil procedural legal personality; consideration of cases by courts; capacity; legal capacity; combating domestic violence. 